\title{
Ecosystem effects of thermal manipulation of a whole lake, Lake Breisjøen, southern Norway (THERMOS project)
}

\author{
E. Lydersen ${ }^{1, *}$, K. J. Aanes ${ }^{1}$, S. Andersen ${ }^{1}$, T. Andersen ${ }^{1}$, P. Brettum ${ }^{1}$, T. Baekken ${ }^{1}$, L. Lien ${ }^{1}$, E. A. Lindstrøm ${ }^{1}$, \\ J. E. Løvik ${ }^{2}$, M. Mjelde ${ }^{1}$, T. J. Oredalen ${ }^{1}$, A. L. Solheim ${ }^{1}$, R. Romstad ${ }^{1}$, and R. F. Wright ${ }^{1}$ \\ ${ }^{1}$ Norwegian Institute for Water Research, Gaustadallèen 21, 0349, Oslo, Norway \\ ${ }^{2}$ Norwegian Institute for Water Research, Sandvikaveien 41, 2312 Ottestad, Norway \\ *now at: Telemark University College, 3800 B $\varnothing$ i Telemark, Norway
}

Received: 23 October 2006 - Published in Hydrol. Earth Syst. Sci. Discuss.: 11 September 2007

Revised: 3 December 2007 - Accepted: 5 February 2008 - Published: 5 March 2008

\begin{abstract}
We conducted a 3-year artificial deepening of the thermocline in the dimictic Lake Breisjøen, southern Norway, by means of a large submerged propeller. An adjacent lake served as untreated reference. The manipulation increased thermocline depth from 6 to $20 \mathrm{~m}$, caused a significant increase in the heat content, and delayed ice-on by about 20 days.

There were only minor changes in water chemistry. Concentrations of sulphate declined, perhaps due to greater reduction of sulphate at the sediment-water interface. Concentrations of particulate carbon and nitrogen decreased, perhaps due to increased sedimentation velocity. Water transparency increased. There was no significant change in concentration of phosphorus, the growth-limiting nutrient.

There were few significant changes in principal biological components. Phytoplankton biomass and productivity did not change, although the chlorophyll- $a$ concentration showed a small decrease. Phytoplankton species richness increased, and the species composition shifted. Growth of periphyton increased. There was no change in the macrophyte community. The manipulation did not affect the zooplankton biodiversity, but caused a significant shift in the relative abundance (measured as biomass) in the two major copepod species. The manipulation did not affect the individual density, but appeared to have changed the vertical distribution of zoobenthos. Fish populations were not affected.

The lake is oligotrophic and clearwater and the manipulation did not change the supply of phosphorus, and thus there were only minor changes in lake chemistry and biology. Effects might be larger in eutrophic and dystrophic lakes in which internal processes are stronger.
\end{abstract}

Correspondence to: R. F. Wright

(richard.wright@niva.no)

\section{Introduction}

Future global change will have many effects on terrestrial and aquatic ecosystems. For lakes one of the major effects will be change in the thermal regime, which in turn can affect ecosystem function and structure at all trophic levels (Schindler et al., 1996). Many lakes in Scandinavia and other cool-temperate regions of the world are dimictic. Dimictic lakes have two circulation periods (spring and autumn) and two stratification periods (summer and winter). Stratification occurs because of temperature-derived density differences. Changes in wind- and temperature regimes affect stratification of dimictic lakes.

Scenarios for future climate change in north temperate regions entail increases in temperature, precipitation, and storminess. For southern Norway, for example, an ensemble of global circulation models run with several emission scenarios indicate an increase of annual temperature of 2 $3^{\circ} \mathrm{C}$ within the next 100 years (RegClim, 2005). Whole-lake manipulation experiments provide one of the few means by which the effects of changed climate can be studied at the whole-ecosystem level. A warming experiment on a whole lake, however, would be prohibitively expensive. Manipulation of the thermal regime of a lake by other means, however, can provide direct experimental information on the ecosystem response to changed water temperature. This information can then be used to infer the sensitivity of ecosystem structure and function to changes in water temperature such as those expected with future climate change.

The THERMOS project (THERMocline Orientated Studies) was such a whole-lake experiment, in which the thermal regime to Lake Breisjøen, southern Norway, was artificially manipulated by deepening the thermocline during

Published by Copernicus Publications on behalf of the European Geosciences Union. 


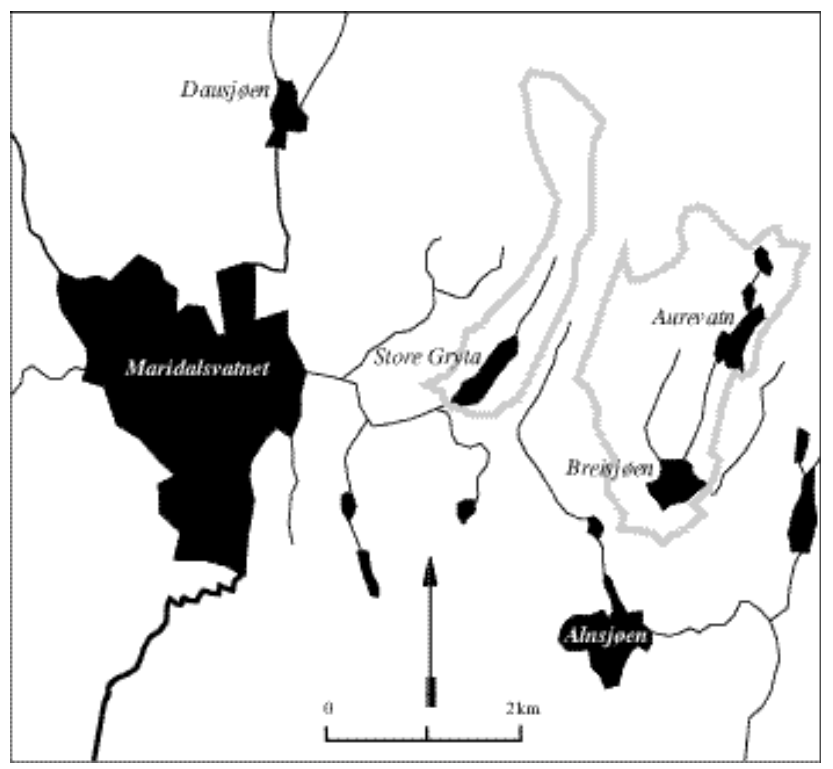

Fig. 1. Map showing location of the studied lakes Breisjøen (manipulated) and Store Gryta (reference), southeastern Norway. Grey line denotes catchment boundary.

the ice-free season by means of a large submerged propeller. An adjacent lake, Store Gryta, served as untreated reference (Fig. 1). Lake thermal regime, water chemistry and all major ecosystem components were studied for a pre-treatment period of three years (1998-2000) and treatment period of three years (2001-2003). The experiment simulated a future climate scenario of increased wind speed and higher temperature. The idea and design of the THERMOS project was inspired by the now-classic whole-lake experiments conducted at the Experimental Lakes Area (ELA), in Ontario, Canada (Schindler, 1991). Here we report the effects of the treatment on thermal properties, water chemistry, primary production, phytoplankton, periphyton, macrophytes, zooplankton, zoobenthos and fish. To date THERMOS has apparently been the world's only whole-lake manipulation aimed at investigating the potential effect of future climate change.

\section{Materials and methods}

\subsection{Experimental design}

The THERMOS project was a paired whole-lake manipulation experiment in which one lake (Breisjøen) is manipulated while the other (Store Gryta) served as reference. The lakes are small $\left(0.1-0.2 \mathrm{~km}^{2}\right)$, moderately deep (20-35 m) (Fig. 2), and have water renewal times of $0.5-0.8$ yrs (Table 1 ). The lakes were monitored for 3 years prior to treatment to determine the inherent differences between the lakes. The changes observed during three years of treatment (2001-2003) at Lake Breisjøen were evaluated relative to the between-lake differences in the pre-treatment period.
The deepening of the thermocline in Lake Breisjøen was accomplished by means of a 2-m diameter slowly-rotating electrically-driven propeller positioned at 4-m depth below a raft anchored in the centre of the lake (Fig. 3). The propeller was operated during the ice-free period for three years 20012003.

\subsection{Site descriptions}

Lake Breisjøen and adjacent Lake Store Gryta are located several $\mathrm{km}$ from Oslo. They serve as reserve drinking water supply, and thus their catchments and lakes themselves are not subject to human disturbance except for occasional removal of tree stems.

The lakes are dimictic, clearwater, and oligotrophic, and thus typical for many lakes in northern boreal forest regions. Bedrock is granitic with young, podsolic soils developed from glacial moraine of similar mineralogy. Vegetation is dominated by a mixed forest of pine (Pinus sylvestris L.), spruce (Picea abies L.) and birch (Betula pubescens L.) with understory of blueberry (Vaccinium myrtillus L.) and heather (Calluna vulgaris L.).

\subsection{Sampling methods}

Meteorological data were taken from the Norwegian Meteorological Institute weather station at Blindern (ca. $10 \mathrm{~km}$ distant) (temperature, precipitation, barometeric pressure, relative humidity, wind speed and direction, and cloud cover) and a station operated by the Norwegian Agricultural University (ca. $35 \mathrm{~km}$ distant) (global radiation).

Water temperature was measured at 15 -min intervals by means of thermistor strings (20 depths in Lake Breisjøen 0.5, $1,2,3,4,5,6,7,8,9,10,11,12,13,14,15,20,25,30,33 \mathrm{~m}$; 15 depths in Lake Store Gryta $0.5,1,2,3,4,5,6,7,8,9,10$, $11,12,15,21 \mathrm{~m})$. Discharge from Lake Store Gryta was measured at a weir on the outlet; areal specific discharge was assumed to hold for Lake Breisjøen as well.

Samples for chemical analysis were taken fortnightly during the ice-free season. Samples were collected by means of 5-m length of hose to give integrated samples for depths of 1-6, (epilimnion), 7-12 (metalimnion), and 26-31 (hypolimnion) $\mathrm{m}$ in Lake Breisjøen, and 1-6, 7-12 and 15-20 in Lake Store Gryta. Secchi disk transparency and $\mathrm{O}_{2}$ concentration were measured in the field. Samples were analysed at NIVA's laboratory by standard accredited methods for major ions, nutrients and organic carbon. Particulate fractions of C, $\mathrm{N}$, and $\mathrm{P}$ were determined on material remaining on $0.45 \mu \mathrm{m}$ GFF filters. Dissolved organic N (org N) was calculated from measured concentrations of the other $\mathrm{N}$ species and defined as:

Org $\mathrm{N}($ dissolved $)=$ total $\mathrm{N}-$ particulate $\mathrm{N}-\mathrm{NO}_{3}-\mathrm{NH}_{4}$, where units are $\mathrm{mol} \mathrm{L}^{-1}$. 


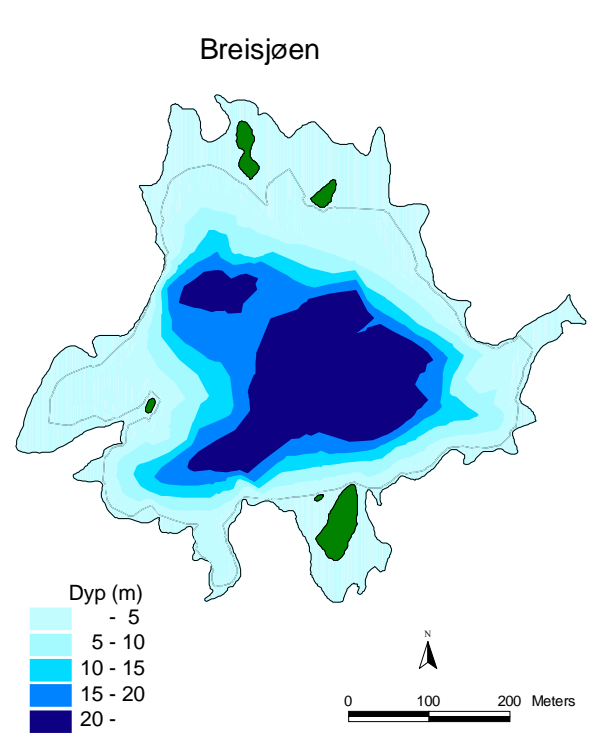

Fig. 2. Bathymetric maps of lakes Breisjøen and Store Gryta.

Chlorophyll- $a$ concentration was measured in the integrated samples. Primary production was measured fortnightly at 12 depths by means of ${ }^{14} \mathrm{C}$ (Faafeng et al., 1982). Quantitative analyses of phytoplankton were made on subsamples of the integrated samples following filtration of $250 \mathrm{~mL}$ through a $90-\mu \mathrm{m}$ net. Periphyton growth was determined monthly during the ice-free season as chlorophyll$a$ contents on clay pots placed at 1,3,5,10 and $15 \mathrm{~m}$ in each lake (Lindstrøm, 1996). Macrophyte composition and percent cover were estimated annually at $40 \times 30 \mathrm{~cm}$ squares (310 in Lake Breisjøen, 36 in Lake Store Gryta) by means of underwater photography. Zooplankton was counted in samples collected fortnightly in each of 3 composite samples (depths 2-6 m, 7-12 m, and 26-31 m in Lake Breisjøen, and 2-6 m, 7-12 $\mathrm{m}$ and $15-20 \mathrm{~m}$ in Lake Store Gryta) filtered through a $90-\mu \mathrm{m}$ mesh net. Bottom fauna was sampled once annually (March) at $0-0.5 \mathrm{~m}$ shore zone and 3 depths (3-4 m, 9-11 m, and deepest point) in each lake. Shore zone samples were collected by means of a kick and net method, while deep water samples were collected by means of 28$\mathrm{cm}^{2}$ diameter sediment corer. Samples were filtered through a 250- $\mu \mathrm{m}$ mesh net. Fish were sampled by means of standard Nordic gillnet series (Saksgard and Hesthagen, 2004) placed each autumn in the lakes. Two combination nets were used, one with mesh sizes $21,26,29,35,40,45$ and $52 \mathrm{~mm}$ and one with 10, 12.5, 16, 22, 25, 30, 38 and $45 \mathrm{~mm}$, respectively. Length, weight and condition were determined. Population size of perch was estimated by re-catch of fin-clipped fish.
Table 1. Morphologic and hydrographic characteristics of lakes Breisjøen (manipulated) and Store Gryta (reference).

\begin{tabular}{llll}
\hline Parameter & Unit & Breisjøen & Store Gryta \\
\hline Latitude & ${ }^{\circ} \mathrm{N}$ & $59^{\circ} 59.3^{\prime}$ & $59^{\circ} 58.8^{\prime}$ \\
Longitude & ${ }^{\circ} \mathrm{E}$ & $11^{\circ} 01.8^{\prime}$ & $10^{\circ} 49.8^{\prime}$ \\
Elevation & $\mathrm{m}$ & 248 & 247 \\
Lake surface area, $A_{o}$ & $\mathrm{~km}^{2}$ & 0.21 & 0.088 \\
Length of shoreline, $L$ & $\mathrm{~km}^{6}$ & 3.82 & 2.49 \\
Lake volume, $V$ & $10^{6} \mathrm{~m}^{3}$ & 2.116 & 0.639 \\
Maximum depth, $z_{m}$ & $\mathrm{~m}$ & 34.5 & 22.0 \\
Mean depth, $\dot{z}$ & $\mathrm{~m}$ & 10.1 & 7.3 \\
Catchment area (incl. lake), $A^{\prime}$ & $\mathrm{km}^{2}$ & 3.66 & 1.76 \\
Mean annual runoff $(1961-90)$ & $\mathrm{mm} \mathrm{yr}^{-1}$ & 534 & 505 \\
Annual outflow, $Q(1998-2002)$ & $10^{6} \mathrm{~m}^{3} \mathrm{yr}^{-1}$ & $2.64 \pm 0.45$ & $1.34 \pm 0.23$ \\
Theoretical water renewal time, $\tau$ & $\mathrm{V} / \mathrm{Q}(\mathrm{yr})$ & $0.82 \pm 0.13$ & $0.49 \pm 0.07$ \\
\hline
\end{tabular}

\subsection{Statistical tests}

Random intervention analysis (RIA) (Carpenter et al., 1989) was used to test for statistical significance of changes that can be ascribed to the manipulation. RIA method is designed specifically for paired-ecosystem experiments, in which one ecosystem is manipulated while the other serves as reference. The method does not assume that the two lakes are identical, but rather that both lakes respond similarly to natural fluctuations. The method requires a pre-treatment monitoring period during which the inherent difference between the lakes is determined, and then a treatment monitoring period. The method tests the hypothesis that the difference between the lakes changed when the treatment was initiated. Here RIA was used to compare paired, 

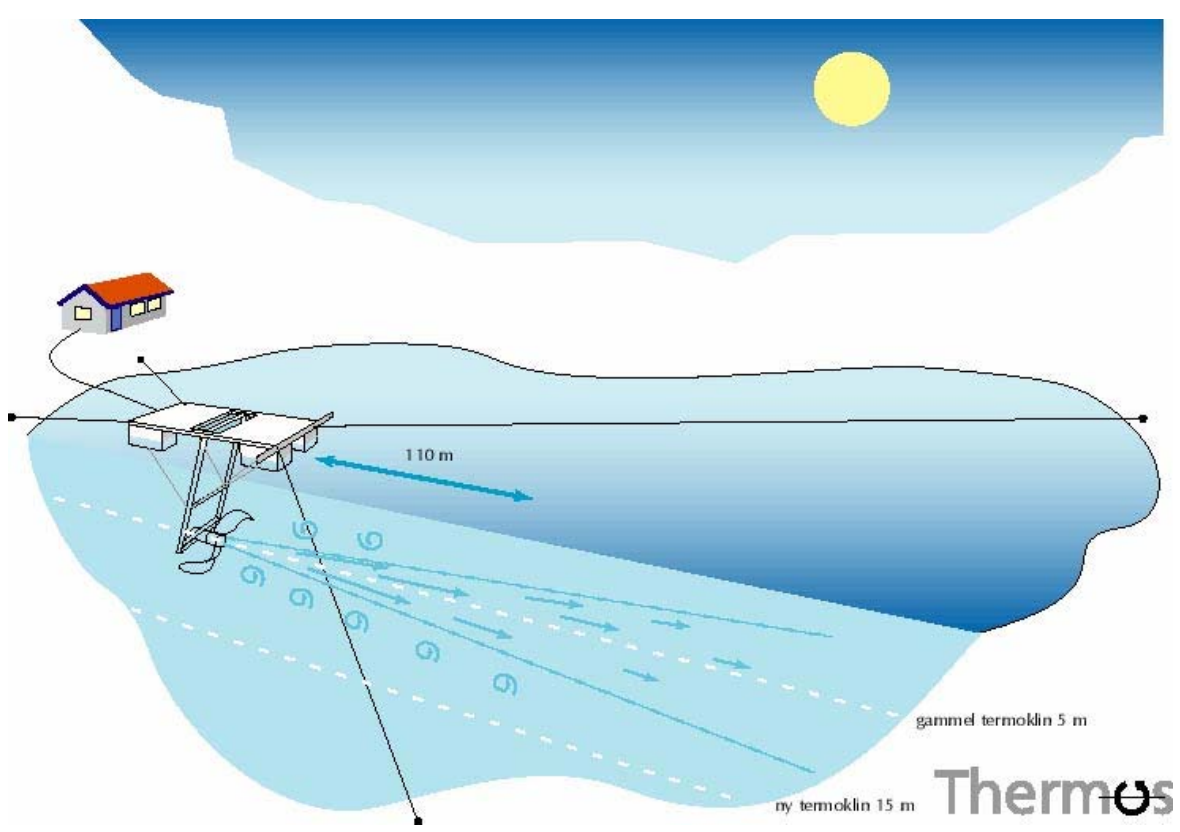

Fig. 3. Schematic sketch of the propeller used to deepen the thermocline in Lake Breisjøen.

chronologically-ordered samples for the six-year data record (three years pre-treatment and three years treatment) from the manipulated (Lake Breisjøen) and reference (Lake Store Gryta) lakes.

\section{Results}

\subsection{Thermal properties}

During the 3 years pre-treatment autumn turnover occurred 1-7 days later in Lake Breisjøen relative to Lake Store Gryta. The turnover in Lake Breisjøen also occurred at somewhat lower water temperature compared with Lake Store Gryta $\left(4.81 \pm 0.43^{\circ} \mathrm{C}\right)$. After the manipulation, turnover in Lake Breisjøen occurred 3-10 days before Lake Store Gryta, and turnover occurred at a significantly higher water temperature $\left(6.86 \pm 0.35^{\circ} \mathrm{C}\right)$ than before the manipulation $\left(4.69 \pm 0.19^{\circ} \mathrm{C}\right)$.

Before the manipulation, Lake Breisjøen had somewhat shorter autumn turnover periods before ice-on than Lake Store Gryta, since autumn circulation occurred later in Lake Breisjøen while ice-on occurred almost simultaneously in the two lakes. After the manipulation, autumn turnover occurred much earlier in Lake Breisjøen and ice-on was significantly delayed. After the manipulation the lake the turnover period was 18-25 days longer than at Lake Store Gryta.

Prior to treatment ice-on occurred on the same date in the two lakes. After the thermocline deepening ice-on in the autumn was delayed by 12-26 days in Lake Breisjøen compared with the reference Lake Store Gryta (Fig. 4). The reason is that the thermocline deepening doubled the heat con- tent of the lake, and thus the lake needed more days to cool to freezing temperature.

During the 6 years of investigation, the average thermocline depth in Lake Store Gryta, at maximum heat content, was $5.5 \pm 0.5 \mathrm{~m}$. Thus, the epilimnion volume constituted $49-59 \%$ of the total lake volume. In Lake Breisjøen the thermocline depth was $5.3 \pm 0.5 \mathrm{~m}$ before the manipulation, and increased to $19.6 \pm 0.5 \mathrm{~m}$ during manipulation (Fig. 5). Thus the epilimnion volume increased from $31-36 \%$ of the total lake volume before manipulation to $86-88 \%$ during manipulation.

During the 3 pre-treatment years the mean epilimnion temperature of Lake Breisjøen was about $1{ }^{\circ} \mathrm{C}$ higher than that of Lake Store Gryta (Fig. 5). Lake Store Gryta is surrounded by much higher and steeper surroundings, which means lower sunlight exposure. This is probably the main reason for lower epilimnion temperature in Lake Store Gryta. Despite the dramatic increase in the epilimnion volume of Lake Breisjøen during the manipulation, the lake still had higher epilimnion temperature than Lake Store Gryta.

The manipulation in Lake Breisjøen increased the mean temperature in the lake by $9.6^{\circ} \mathrm{C}$ at time of maximum heat content, from $10.7 \pm 0.4^{\circ} \mathrm{C}$ before manipulation to $17.4 \pm 1.6^{\circ} \mathrm{C}$ during manipulation (Fig. 5).

Prior to manipulation both lakes had positive heterograde $\mathrm{O}_{2}$-curves $\left(\mathrm{O}_{2}\right.$ maximum in metalimnion), a common condition in clearwater lakes with relatively shallow thermoclines. During manipulation Lake Breisjøen no longer had a positive heterograde $\mathrm{O}_{2}$-curve. The significant deepening of the thermocline also significantly reduced the stratification stability. 
Prior to manipulation Lake Breisjøen had somewhat lower concentrations of dissolved $\mathrm{O}_{2}$ than Lake Store Gryta. This is likely because Lake Breisjøen is somewhat more nutrient rich and receives somewhat more allochthonous compounds. During manipulation the $\mathrm{O}_{2}$ concentration in Lake Breisjøen increased slightly and was somewhat higher than in Lake Store Gryta.

The three years before manipulation the Secchi-disk transparency of Lake Breisjøen and Lake Store Gryta was $7.9 \pm 1.8 \mathrm{~m}$ and $11.9 \pm 1.7 \mathrm{~m}$, respectively. During manipulation transparency in Lake Breisjøen increased to $9.8 \pm 1.1 \mathrm{~m}$, while it decreased slightly Lake Store Gryta to $10.7 \pm 1.6 \mathrm{~m}$. The manipulation caused an increase of about $3 \mathrm{~m}$ (Table 2). Manipulation also resulted in less pronounced seasonal variations in transparency.

\subsection{Water chemistry}

Lakes Breisjøen and Store Gryta are softwaters with low concentrations of solutes, moderate $\mathrm{pH}$ and very low concentrations of nutrients. Total $\mathrm{P}$ concentrations are generally only $2-3 \mu \mathrm{g} \mathrm{L}^{-1}$. Concentrations of total organic carbon are also low, and the lakes have moderately high transparency (Table 2).

Over the six-year period of observations there was a significant decline $(\mathrm{p}<0.001)$ in concentration of sulphate in both lakes (Table 2, Fig. 6). The decline was $8 \mu \mathrm{eq} \mathrm{L}^{-1} \mathrm{yr}^{-1}$ at Breisjøen and $7 \mu \mathrm{eq} \mathrm{L}^{-1} \mathrm{yr}^{-1}$ in Store Gryta. This is a direct consequence of the large decrease (40-60\%) in atmospheric deposition of sulphur since the mid-1980s. A similar reduction has been well documented in acidified lakes in Norway (Skjelkvåle et al., 2001). There was also a small decline $\left(3 \mu \mathrm{eq} \mathrm{L}-1 \mathrm{yr}^{-} 1\right)$ in the concentration of chloride $(\mathrm{Cl})$ in both lakes, probably due to lower inputs of seasalts in precipitation over this period. There were no significant decreases in concentrations of base cations $\left(\mathrm{Ca}^{2+}, \mathrm{Mg}^{2+}, \mathrm{Na}^{+}\right.$, $\mathrm{K}^{+}$). The decline in concentrations of strong acid anions $\mathrm{SO}_{4}$ and $\mathrm{Cl}$ in Lake Breisjøen was in part matched by a small $\left(5.4 \mu \mathrm{eq} \mathrm{L}^{-1} \mathrm{yr}^{-1}\right)$ but significant $(\mathrm{p}<0.05)$ increase in acid neutralising capacity (ANC). There was no statisticallysignificant trend in ANC concentration in Lake Store Gryta.

The manipulation resulted in only minor changes in water chemistry. Tests by Random Intervention Analysis (RIA) revealed that the 3-years of thermocline manipulation caused only minor changes in concentrations of major ions in Lake Breisjøen relative to Lake Store Gryta (Table 2). Sulphate concentrations decreased (Fig. 6), ammonium concentrations increased, and $\mathrm{pH}$ concentrations increased in Lake Breisjøen relative to Store Gryta.

The manipulation also resulted in changes in concentrations of carbon and nitrogen species in Lake Breisjøen relative to Lake Store Gryta (Table 2). Concentrations of total organic carbon (TOC) decreased (Fig. 7), mostly due to decreased concentrations of particulate organic C (Fig. 8). Particulate organic $\mathrm{N}$ also decreased in Lake Breisjøen relative
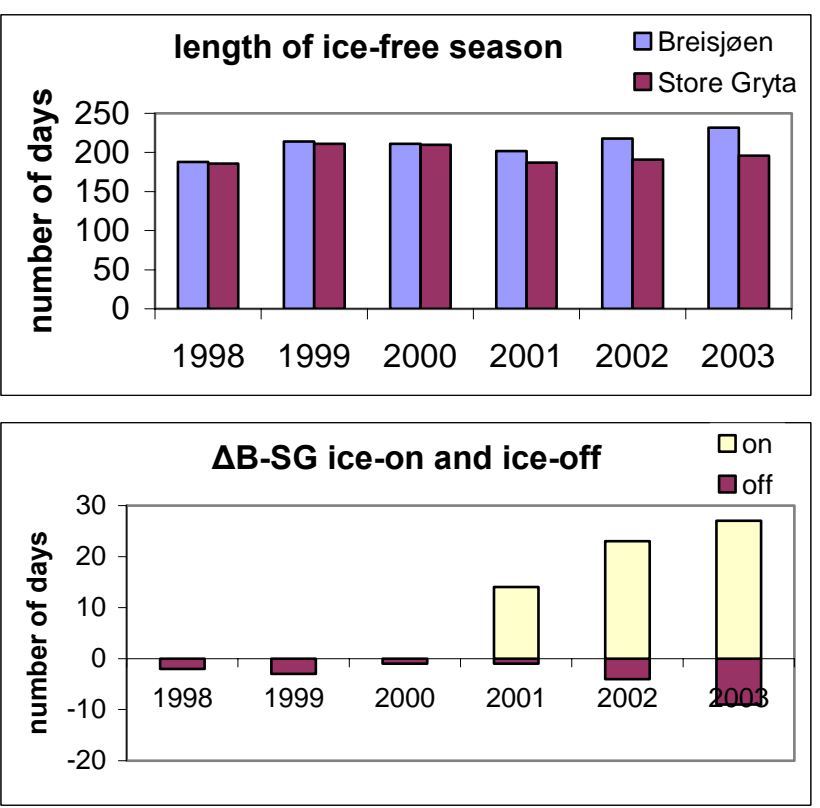

Fig. 4. Top panel: length of ice-free season (number of days) at Lake Breisjøen (B; manipulated) and Store Gryta (S; reference). Bottom panel: difference in date of ice-off (spring) and ice-on (autumn).

to Store Gryta. The decreased particulate matter concentration can explain the observed decrease in turbidity (Table 2).

There were no significant changes in concentrations of $P$ species in Lake Breisjøen relative to Lake Store Gryta following treatment. However, the $\mathrm{C} / \mathrm{P}$ ratio of particulate matter decreased during treatment (Fig. 11). This is most likely due to increased light limitation of the phytoplankton, and shifts towards more mixotrophic algae (see below).

\subsection{Biology}

\subsubsection{Phytoplankton}

Algal biomass and primary production were quite low in the lakes (Table 3). The phytoplankton community structure showed a quite even distribution of the different classes, and their relative distribution was very similar in the two lakes before the manipulation (Fig. 9). Even distribution of algal classes is quite commonly observed in oligotrophic lakes in general. The total algae biomass was low $(<0.2 \mathrm{mg} / \mathrm{L}$, Table 3). Highest biomass was found in the metalimnion of both lakes, and caused positive heterograde $\mathrm{O}_{2}$-profiles.

The manipulation of Lake Breisjøen caused only minor changes in phytoplankton production. Random Intervention analysis (RIA) indicates that the manipulation did not significantly change phytoplankton biomass in Lake Breisjøen (Table 3), although the epilimnion biomass decreased (Fig. 9).

Both lakes had a primary production peak in May (spring maximum), a decline in June, and one or two summer/early 
Table 2. Chemical and physical characteristics of lakes Breisjøen (B) and Store Gryta (SG). Values are whole-lake volume-weighted mean concentrations \pm standard deviation based on samples collected fortnightly or monthly during the ice-free season. Pre-treatment 1998-2000; treatment 2001-2003. Also shown are differences in concentrations in Breisjøen (B) relative to Store Gryta (G), and change in difference for the 3 treatment relative to 3 pre-treatment years. The change ascribable to treatment was tested by Random Intervention Analysis. Statistical significance: NS not significant; $* \mathrm{p}<0.1 ; * * \mathrm{p}<0.05 ; * * * \mathrm{p}<0.01$.

\begin{tabular}{|c|c|c|c|c|c|c|c|c|c|c|c|c|c|}
\hline \multirow[t]{2}{*}{ Parameter } & \multirow[t]{2}{*}{ Unit } & \multicolumn{3}{|c|}{ pre (1998-2000) } & \multicolumn{3}{|c|}{ treat $(2001-2003)$} & \multicolumn{2}{|c|}{ Change treat-pre } & \multicolumn{3}{|c|}{ delta B-SG } & \multirow{2}{*}{$\begin{array}{l}\text { RIA } \\
\text { signif }\end{array}$} \\
\hline & & $\mathrm{n}$ & B & SG & $\mathrm{n}$ & B & SG & B & G & pre & treat & treat-pre & \\
\hline cond & $\mathrm{mS} \mathrm{m}^{-1}$ & 42 & $3.11 \pm 0.13$ & $3.23 \pm 0.15$ & 32 & $2.76 \pm 0.06$ & $2.86 \pm 0.11$ & -0.35 & -0.37 & -0.12 & -0.11 & 0.01 & NS \\
\hline $\mathrm{pH}$ & & 42 & $6.65 \pm 0.26$ & $6.73 \pm 0.37$ & 32 & $6.72 \pm 0.14$ & $6.73 \pm 0.25$ & 0.07 & 0.00 & -0.08 & -0.01 & 0.07 & $* * *$ \\
\hline $\mathrm{Ca}$ & $\mu \mathrm{eq} \mathrm{L}^{-1}$ & 23 & $134 \pm 7$ & $131 \pm 9$ & 20 & $125 \pm 13$ & $121 \pm 14$ & -9 & -10 & 3 & 4 & 1 & NS \\
\hline $\mathrm{Mg}$ & $\mu \mathrm{eq} \mathrm{L}^{-1}$ & 23 & $53 \pm 3$ & $60 \pm 4$ & 20 & $49 \pm 4$ & $56 \pm 6$ & -4 & -4 & -7 & -7 & 0 & NS \\
\hline $\mathrm{Na}$ & $\mu$ eq $\mathrm{L}^{-1}$ & 23 & $77 \pm 4$ & $83 \pm 5$ & 20 & $71 \pm 2$ & $77 \pm 4$ & -6 & -6 & -6 & -6 & 0 & NS \\
\hline $\mathrm{K}$ & $\mu \mathrm{eq} \mathrm{L}^{-1}$ & 23 & $7 \pm 1$ & $8 \pm 1$ & 20 & $7 \pm 0$ & $8 \pm 0$ & 0 & 0 & -1 & -1 & 0 & NS \\
\hline $\mathrm{Cl}$ & $\mu$ eq $\mathrm{L}^{-1}$ & 23 & $55 \pm 6$ & $55 \pm 6$ & 20 & $45 \pm 2$ & $44 \pm 3$ & -10 & -11 & 0 & 1 & 1 & NS \\
\hline $\mathrm{SO}_{4}$ & $\mu$ eq $\mathrm{L}^{-1}$ & 23 & $110 \pm 10$ & $114 \pm 9$ & 20 & $84 \pm 5$ & $90 \pm 4$ & -26 & -24 & -4 & -6 & -2 & $* * *$ \\
\hline $\mathrm{NO}_{3}$ & $\mu \mathrm{eq} \mathrm{L}^{-1}$ & 39 & $5.2 \pm 1.9$ & $4.9 \pm 1.6$ & 31 & $7.4 \pm 1.7$ & $6.9 \pm 1.7$ & 2.2 & 2.0 & 0.3 & 0.5 & 0.2 & $* *$ \\
\hline $\mathrm{NH}_{4}$ & $\mu \mathrm{eq} \mathrm{L}^{-1}$ & 42 & $0.7 \pm 0.4$ & $0.6 \pm 0.2$ & 32 & $0.9 \pm 0.4$ & $0.6 \pm 0.2$ & 0.2 & 0.0 & 0.1 & 0.3 & 0.2 & $* * *$ \\
\hline Alkalinity & $\mu \mathrm{eq} \mathrm{L}^{-1}$ & 42 & $77 \pm 7$ & $89 \pm 9$ & 32 & $78 \pm 9$ & $87 \pm 14$ & 1 & -2 & -12 & -9 & 3 & NS \\
\hline ANC & $\mu \mathrm{eq} \mathrm{L}^{-1}$ & 23 & $100 \pm 8$ & $107 \pm 10$ & 20 & $113 \pm 19$ & $119 \pm 22$ & 13 & 12 & -7 & -5 & 2 & NS \\
\hline total N & $\mu \mathrm{mol} \mathrm{L}^{-1}$ & 42 & $16.7 \pm 1.9$ & $13.3 \pm 1.6$ & 32 & $18.8 \pm 2.1$ & $15.9 \pm 1.9$ & 2.1 & 2.6 & 3.4 & 2.9 & -0.5 & $* *$ \\
\hline $\operatorname{org} \mathrm{N}$ & $\mu \mathrm{mol} \mathrm{L}^{-1}$ & 39 & $9.9 \pm 2.9$ & $7.1 \pm 2.1$ & 31 & $10 \pm 0.8$ & $8.3 \pm 1.1$ & 0.1 & 1.2 & 2.8 & 1.7 & -1.1 & $* * *$ \\
\hline part $\mathrm{N}$ & $\mu \mathrm{mol} \mathrm{L}^{-1}$ & 42 & $2.4 \pm 0.8$ & $1.6 \pm 0.5$ & 32 & $2.0 \pm 0.9$ & $1.7 \pm 0.7$ & -0.4 & 0.1 & 0.8 & 0.3 & -0.5 & $* * *$ \\
\hline total P & $\mu \mathrm{mol} \mathrm{L}^{-1}$ & 42 & $0.10 \pm 0.02$ & $0.07 \pm 0.01$ & 32 & $0.08 \pm 0.02$ & $0.03 \pm 0.04$ & -0.02 & -0.04 & 0.03 & 0.05 & 0.02 & NS \\
\hline part $\mathrm{P}$ & $\mu \mathrm{mol} \mathrm{L}^{-1}$ & 42 & $0.08 \pm 0.01$ & $0.06 \pm 0.01$ & 32 & $0.06 \pm 0.01$ & $0.02 \pm 0.01$ & -0.02 & -0.04 & 0.02 & 0.04 & 0.02 & NS \\
\hline $\mathrm{PO}_{4}$ & $\mu \mathrm{mol} \mathrm{L}^{-1}$ & 42 & $0.02 \pm 0.01$ & $0.01 \pm 0.01$ & 32 & $0.02 \pm 0.02$ & $0.01 \pm 0.01$ & 0.00 & 0.00 & 0.01 & 0.01 & 0.00 & NS \\
\hline TOC & $\mu \mathrm{mol} \mathrm{L}^{-1}$ & 42 & $225 \pm 33$ & $158 \pm 25$ & 32 & $228 \pm 27$ & $168 \pm 18$ & 3 & 10 & 67 & 60 & -7 & $* * *$ \\
\hline part C & $\mu \mathrm{mol} \mathrm{L}^{-1}$ & 42 & $27 \pm 6$ & $20 \pm 3$ & 32 & $23 \pm 4$ & $21 \pm 3$ & -4 & 1 & 7 & 2 & -5 & $* * *$ \\
\hline Secchi disk & $\mathrm{m}$ & 42 & $7.9 \pm 1.8$ & $11.9 \pm 1.7$ & 38 & $9.8 \pm 1.1$ & $10.7 \pm 1.6$ & 1.9 & -1.2 & -4.0 & -0.9 & 3.1 & $* * *$ \\
\hline Turbidity & FTU & 42 & $0.52 \pm 0.18$ & $0.36 \pm 0.17$ & 32 & $0.49 \pm 0.08$ & $0.44 \pm 0.08$ & -0.03 & 0.08 & 0.16 & 0.05 & -0.11 & $* * *$ \\
\hline Colour & $\mathrm{mgPtL}^{-1}$ & 42 & $9.5 \pm 3.5$ & $6.2 \pm 2.6$ & 32 & $10.5 \pm 3.0$ & $6.7 \pm 1.9$ & 1.0 & 0.5 & 3.3 & 3.8 & 0.5 & NS \\
\hline UV & OD254 nm & 42 & $0.077 \pm 0.016$ & $0.054 \pm 0.013$ & 32 & $0.080 \pm 0.015$ & $0.054 \pm 0.011$ & 0.003 & 0.000 & 0.023 & 0.026 & 0.003 & $* *$ \\
\hline
\end{tabular}

autumn maxima. The manipulation caused no change in primary production in Lake Breisjøen relative to Store Gryta (Table 3).

Lake Breisjøn did not show any change in chlorophyll- $a$ during the manipulation. In the reference Lake Store Gryta the chlorophyll- $a$ concentration increased slightly (Table 3 ). The biomass-specific chlorophyll- $a$ (per unit algal volume) showed clear seasonal and vertical variations in both lakes. In Lake Store Gryta it increased successively with depth from the lake surface to the lake bottom. The average chlorophyll$a$ content was about twice as high in the hypolimnion (15$20 \mathrm{~m})$ as in the epilimnion $(0-6 \mathrm{~m})$. This is most likely due to photo adaptation. The same tendency of increasing chlorophyll-a/algae volume ratio by depth was also observed in Lake Breisjøen, but at the largest depths (26-31 m) the ratio decreased again.

There are several indications of qualitative changes in phytoplankton species composition during the manipulation (Fig. 9). There was a slight decrease in phytoplankton biomass in the epilimnion during the treatment years compared to the pre-treatment period in Lake Breisjøen, whereas in the reference Lake Gryta, the phytoplankton biomass increased slightly. The taxonomic composition also changed in Lake Breisjøen compared to Lake Store Gryta. The most conspicuous changes were the decrease of autotrophic algal classes, such as chlorophytes and diatoms, and the increase in the mixotrophic dinoflagellates. The chlorophytes decreased from 26 to $16 \mathrm{mg} \mathrm{m}^{-3}$ in Lake Breisjøen, in contrast to the increase from 28 to $38 \mathrm{mg} \mathrm{m}^{-3}$ in Lake Store Gryta. The diatoms decreased in both lakes, but more so in Lake Breisjøen than Lake Store Gryta. The dinoflagellates increased from 28 to $41 \mathrm{mg} \mathrm{m}^{-3}$ in Lake Breisjøen, whereas they remained unchanged in Lake Store Gryta.

The cyanobacteria increased slightly in both lakes but they never exceeded $5 \%$ of total biomass, probably due to the severe P-limitation in both these lakes. The chrysophytes did not change after mixing in either lake, but were important components $(25-30 \%)$ of the phytoplankton community in both lakes both before and during treatment.

Among the Dinophyceae, an increase in Peridinium umbonatum (old name: P. inconspiciuum) was observed after the manipulation in Lake Breisjøen. Also two other species increased after the manipulation, i.e. Gymnodinium uberrimum and Gymnodinum lacustre. A decrease in the algae biomass of Chlorophyceae was recorded after the manipulation, with Oocystis submarina v. variabilis and Monoraphidium griffithii as the most common species. The diatom Cyclotella kützingiana was the predominant species in both 

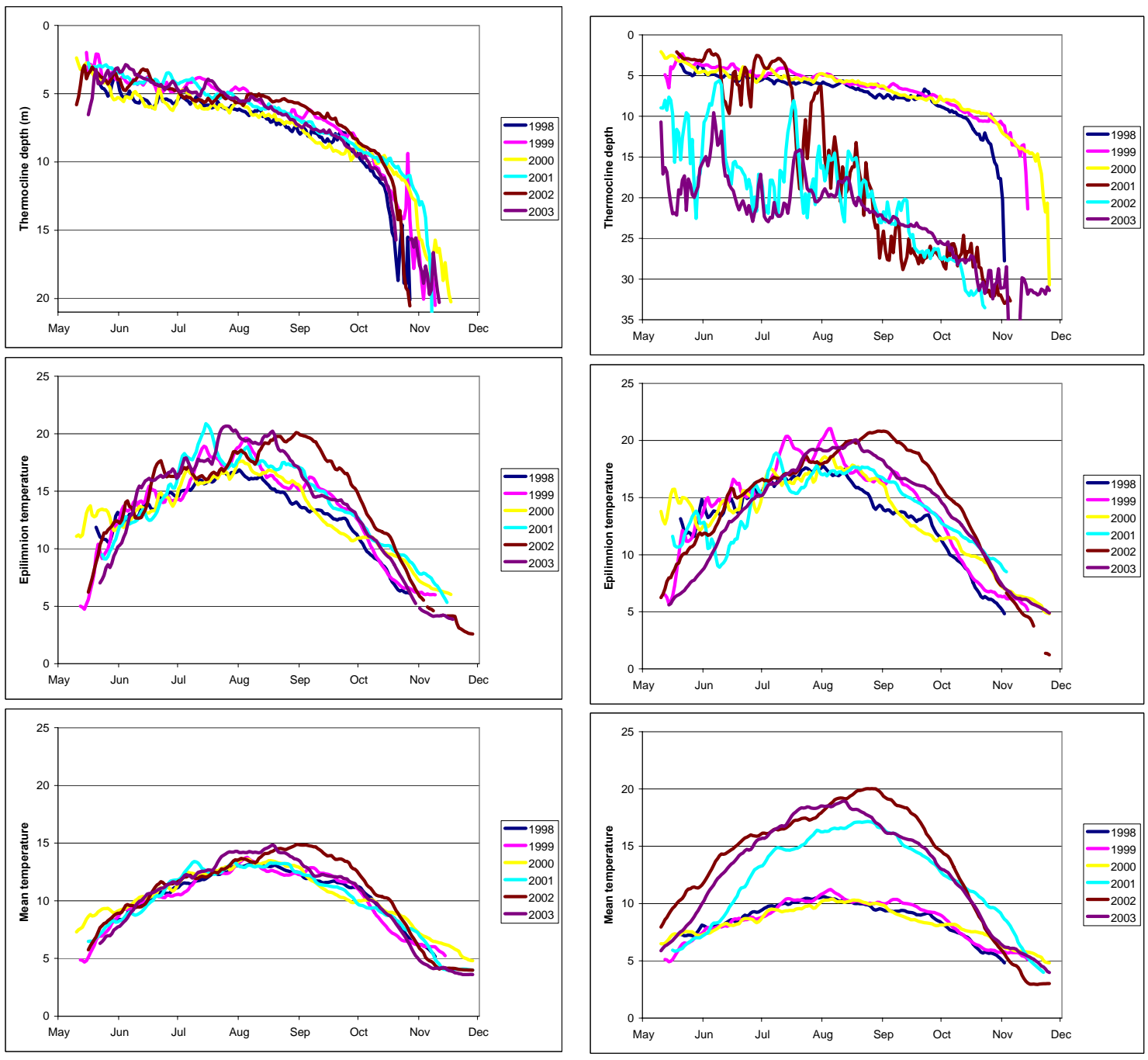

Fig. 5. Thermocline depth, epilimnion temperature and mean lake temperature at lakes Store Gryta (reference; left-hand panels) and Breisjøen (treatment; right-hand panels) during the ice-free periods prior to treatment 1998-2000 and treatment (2001-2003).

lakes, but in both lakes a decrease was observed from 1998 to 2003. The manipulation in Lake Breisjøen accelerated this decline.

There was a slight increase in the number of phytoplankton taxa after the thermocline deepening. Before the manipulation 104 species/genera were recorded in Lake Breisjøen compared with 83 in Lake Store Gryta. During the manipulation, the total number increased to 109 in Lake Breisjøen, while decreased to 77 in Lake Store Gryta (Table 4).

\subsubsection{Periphyton}

Periphyton biomass (as determined by growth during one month on an artificial surface) was also low in both lakes. The lakes had almost the same species composition of periphyton, with Bacillariophyceae species as the dominant class. After the manipulation the growth potential of peri- phyton increased, both in terms of dry weight $\left(\mathrm{mg} \mathrm{cm}^{-2}\right)$ and chlorophyll- $a\left(\mu \mathrm{g} \mathrm{cm}^{-2}\right)$ (Table 3). The largest nominal increase was observed in the depth interval $1-3 \mathrm{~m}$. The largest percentage increase, however, was found at $10 \mathrm{~m}$ depth, but here the biomass was much lower. Both lakes showed a clear tendency of increasing chlorophyll- $a$ content in periphyton by depth. A small increase in the chlorophyll- $a$ concentration was documented in Lake Breisjøen during the thermocline deepening.

\subsubsection{Macrophytes}

Prior to the manipulation the most significant difference between the lakes was in the macrophyte community. The lakes differed with respect to bottom substrate and depth profile characteristics. But most important was probably the fact that in the years prior to 1998 extraction of drinking 


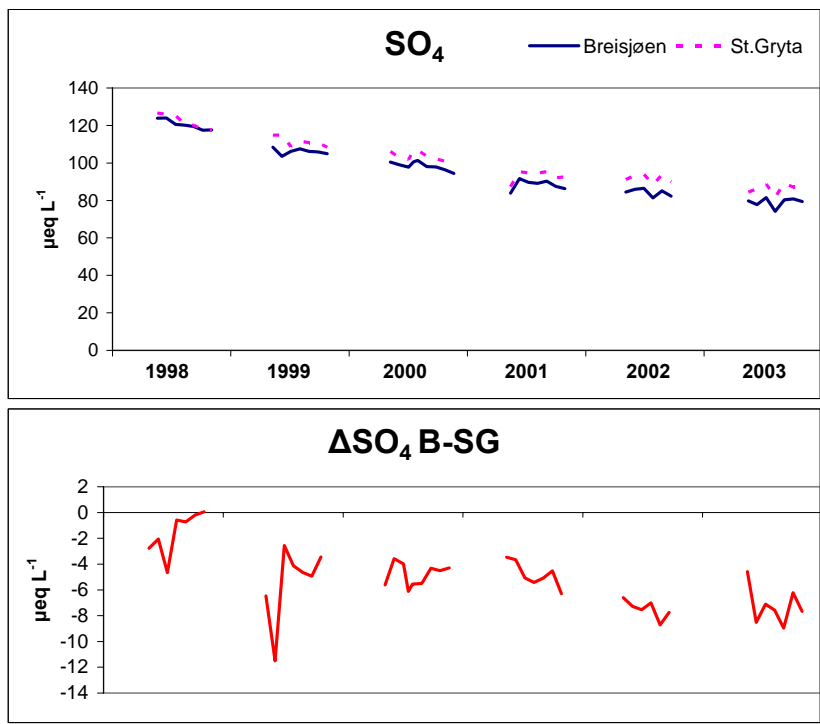

Fig. 6. Volume-weighted, whole-lake concentrations of sulphate in Lakes Breisjøen (treatment) and Store Gryta (reference) (upper panel) and difference in concentrations during the ice-free season over 6 years (lower panel). Treatment began in 2001 .

water from Lake Breisjøen resulted in fluctuations of the water level. There was no extraction of drinking water in years subsequent to 1998. Juncus bulbosus predominated in Lake Breisjøen and was found down to approximately $4 \mathrm{~m}$ depth. The lower limit at $4 \mathrm{~m}$ is unusual and is probably due to the water level fluctuations and better light conditions in Breisjøen compared to other Juncus lakes. Luronium natans was fairly common in Breisjøen with a patchy distribution at $0.5-3.5 \mathrm{~m}$ depth. It appeared both flowering with floating leaves and with submerged rosette leaves. The species is one of the most endangered aquatic plant species in Norway (DN 1999), as well as in rest of Europe. The species is only known from 5 lakes nearby Oslo. In Lake Store Gryta the macrophyte community was dominated by scattered stands of nymphaeides, primarily Potamogeton natans, Nuphar lutea and Nymphaea alba coll. Isoetids were not observed in Lake Store Gryta, while 5 species of isoetids were found in Lake Breisjøen. There were no changes in macrophytes that could be ascribed to the manipulation.

\subsubsection{Zooplankton}

The composition of zooplankton was very similar in the two lakes. Lake Breisjøen hosted a few more species than Lake Store Gryta. In Lake Breisjøen 8 cladoceran species, 7 copepod species and 17 species of rotifers were found, while in Lake Store Gryta, 7 cladoceran species, 8 copepod species and 13 species of rotifers were recorded. Bosmina longispina and Holopedium gibberum were the dominant cladocera, while Thermocylops oithonoides and Cyclops scutifer were the dominant copepods. Among the rotifers,

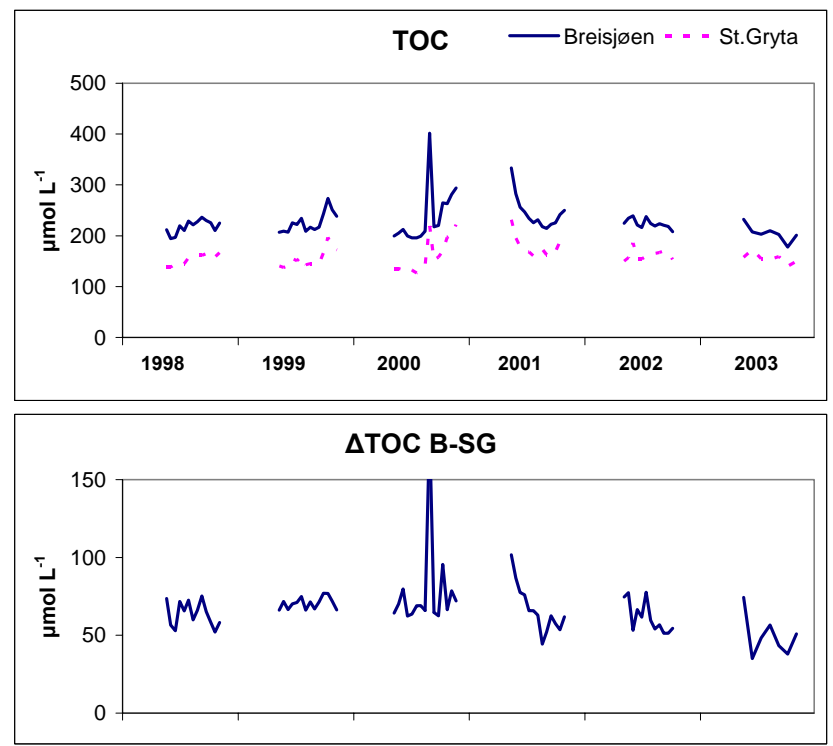

Fig. 7. Volume-weighted, whole-lake concentrations of total organic carbon (TOC) in Lakes Breisjøen (treatment) and Store Gryta (reference) (upper panel) and difference in concentrations during the ice-free season over 6 years (lower panel).

Conochilus unicornis was totally dominant. Cladocerans dominated the zooplankton in the epi- and meta-limnion, while copepods dominated in the hypolimnion. One difference between the lakes was the relatively large population of Daphnia galeata in Lake Store Gryta, a species not observed in Lake Breisjøen. Correspondingly, Lake Breisjøen hosted a good population of Daphnia cristata, a species not observed in Lake Store Gryta. The 3-year manipulation in Lake Breisjøen did not affect the zooplankton biodiversity in the lake.

The total biomass of zooplankton (Table 3) was low in both lakes. Zooplankton biomass was generally higher than phytoplankton biomass in both lakes. The fact that the zooplankton biomass is larger than the phytoplankton biomass indicates that the zooplankton must also feed on bacteria and detrital particles. Phytoplankton and zooplankton together, constituted only about $10 \%$ of the particulate carbon pool in the free (pelagic) water body of the two lakes.

Although the manipulation caused no significant change in the total biomass of zooplankton, there was a significant $(\mathrm{p}<0.1$ level) decrease in cladocera biomass and an increase in copepod biomass in Lake Breisjøen relative to Lake Store Gryta (Table 3, Fig. 10). This shift was primarily due to a decrease in the relative abundance of the cladoceran Bosmina longispina and an increase of the copepod Thermocyclops oithonoides. 

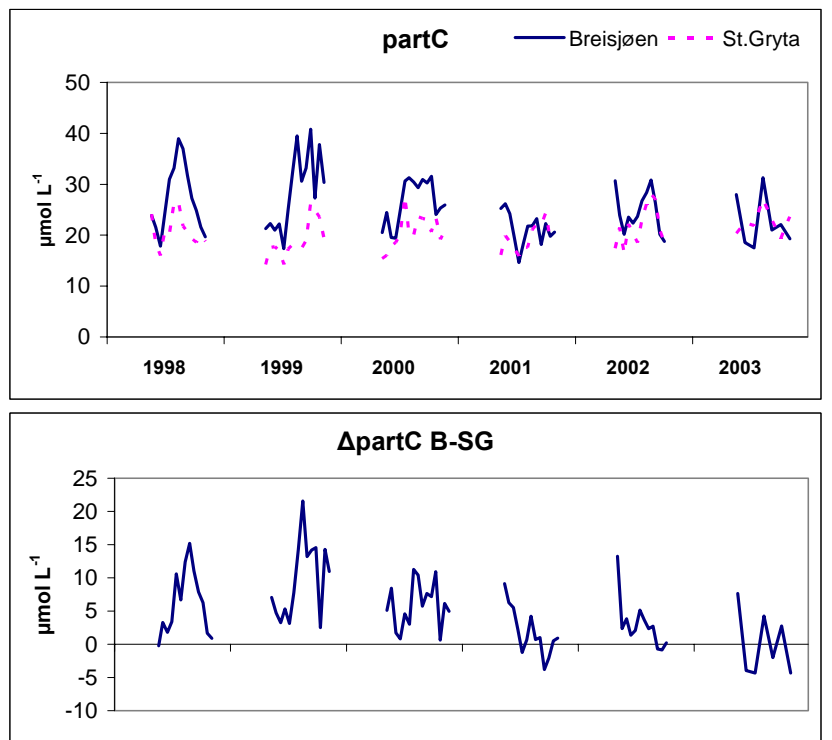

Fig. 8. Volume-weighted, whole-lake concentrations of particulate organic carbon (part C) in Lakes Breisjøen (treatment) and Store Gryta (reference) (upper panel) and difference in concentrations during the ice-free season over 6 years (lower panel).

\subsubsection{Zoobenthos}

The benthic fauna in both lakes was dominated by chironomids (Chironomidaea) with lesser numbers of ostracods (Ostracoda) and oligochaetes (Oligochæta). In the lake shore habitats with vegetation, chironomids predominated in both lakes and there were on the average 2800 individuals $\mathrm{m}^{-2}$ in Lake Breisjøen and 1600 individuals $\mathrm{m}^{-2}$ in Lake Store Gryta.

The manipulation did not affect the abundance (density of individuals), but appeared to change the vertical distribution of zoobenthos. Before the manipulation the highest densities were recorded at stations located at a depth of $10 \mathrm{~m}$, while after the manipulation the highest densities were recorded at $34 \mathrm{~m}$. This change in zoobenthos biomass distribution is probably linked to the increase in concentration of phytoplankton and zooplankton at greater after the manipulation. In Lake Store Gryta in all six years the highest density of benthos was recorded at the depth interval $4-10 \mathrm{~m}$.

During the manipulation, the abundance of chironomids and oligochaetes decreased in Lake Breisjøen, while the density of cyclopoid copepods and ostracods increased. In Lake Store Gryta chironomids decreased slightly, oligochaetes decreased, and ostracods decreased moderately. Cyclopoid copepods, on the other hand, increased. During the manipulation in Lake Breisjøen there was a clear reduction in density of oligochaetes and increased densities of both cyclopoid copepods and ostracods compared with the Lake Store Gryta. The increase of cyclopoid copepods might be linked to the increase in the zooplankton Thermocylops oithonoides during
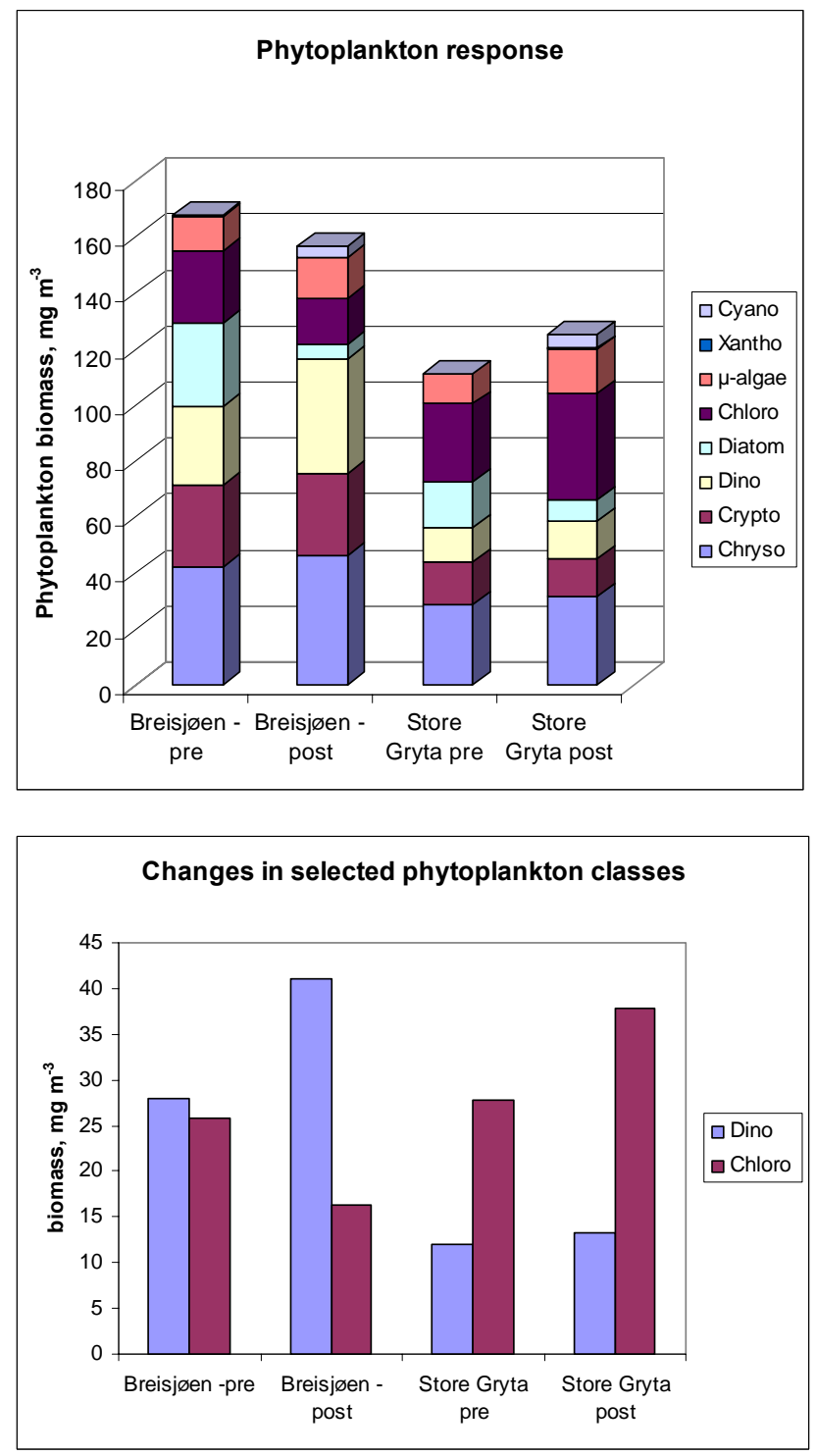

Fig. 9. Upper panel: Whole-lake volume-weighted biomass of major groups of phytoplankton in Lakes Breisjøen and Store Gryta in the ice-free seasons pre-treatment (1998-2000) and treatment (2001-2003). Lower panel: Changes in biomass of Dinophyceae and Chlorophyceae.

the manipulation. This might have resulted in larger densities of nauplius larvae of this species in the sediments, and thereby recorded as an increase of copepods in zoobenthos.

\subsubsection{Fish}

Both lakes host healthy populations of brown trout (Salmo trutta) and perch (Perca fluviatilis). As determined by recatch of fin-clipped perch, the perch population was significantly larger in Lake Breisjøen (about 50-70 individuals/ha) than in Lake Store Gryta (14-16 individuals/ha). Lake Store Gryta had a larger brown trout population. Both lakes had 

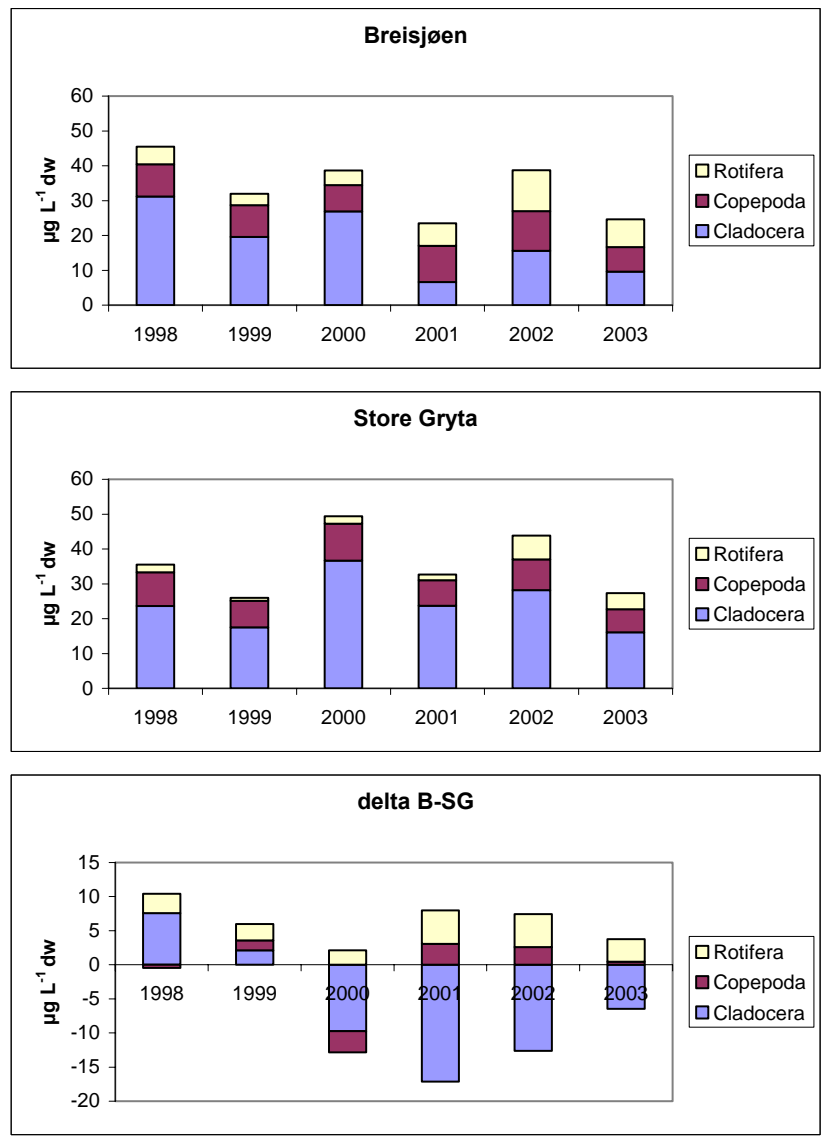

Fig. 10. Whole-lake volume weighted biomass of major groups of zooplankton in Lakes Breisjøen and Store Gryta 1998-2003.

minor populations of arctic char (Salvelinus alpinus) and minnow (Phoxinus phoxinus). The 3-year manipulation had no significant effect on the size, condition factor or population density of perch and brown trout.

\section{Discussion}

The rather dramatic manipulation of the thermocline at Lake Breisjøen resulted in large changes in thermal properties but surprisingly few and only small changes in water chemistry and biology. That the effects were absent or minor was apparent from visual inspection of the data. This general impression was supported by the statistical test, Random Intervention Analysis, which indicated only a few significant effects that could be ascribed to the manipulation. RIA is one of the few tools available for testing the "before-after-controlimpact" (BACI) experimental design used here in THERMOS. Murtaugh (2002) points out that RIA should be used with caution as it can indicate significant effects in cases where no intervention was made. He suggests that graphical displays, expert judgment and common sense be used to make plausible interpretations of paired time series data.

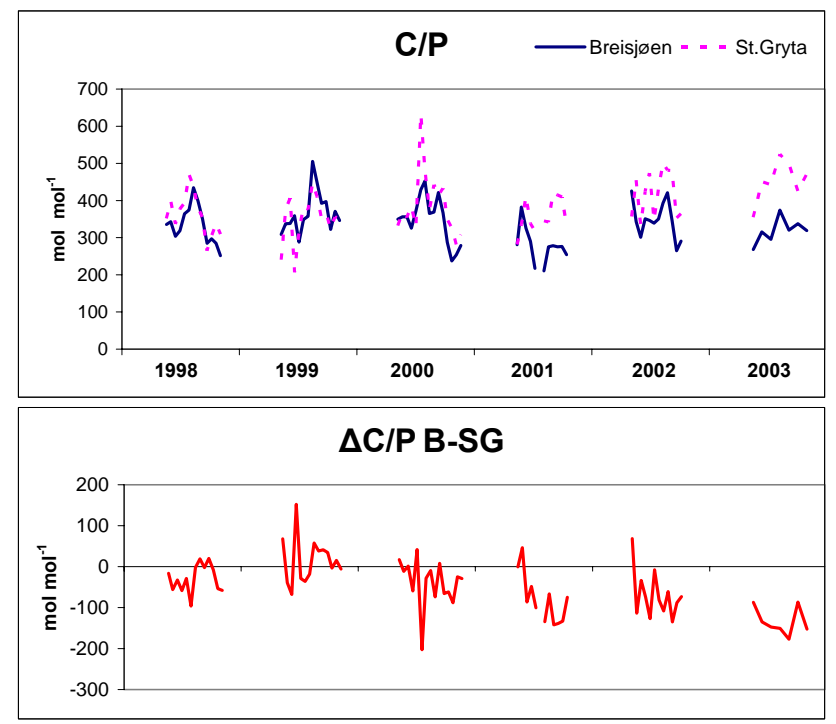

Fig. 11. Volume-weighted, whole-lake molar ratios of carbon to phosphorus $(\mathrm{C} / \mathrm{P})$ in particulate matter in Lakes Breisjøen (treatment) and Store Gryta (reference) (upper panel) and difference in concentrations during the ice-free season over 6 years (lower panel).

A longer turnover period might be of significance for many lakes, especially warm and eutrophic lakes, since increased circulation increases the possibility of oxygen saturation in the entire lake water profile (Danis et al., 2004). At Lake Breisjøen the manipulation resulted in autumn turnover at a significantly higher water temperature, and this may reduce the oxygenation since the solubility of gases is lower at higher temperature. Overall, however, improved $\mathrm{O}_{2}$ saturation should be expected, since ice-on also occurred at a lower mean temperature after manipulation.

Both lakes are oligotrophic, clearwater lakes with low amounts of allochthonous and autochthonous organic matter. Since both lakes also are dimictic (turnover both during spring and autumn), the conditions for dissolved molecular $\mathrm{O}_{2}$ are generally good. Both lakes had positive heterograde $\mathrm{O}_{2}$-curves $\left(\mathrm{O}_{2}\right.$ maximum in metalimnion $)$, a common condition in clearwater lakes with relatively shallow thermoclines. Under such conditions the compensation depth for primary producers is located below the metalimnion. The compensation depth is primarily dependent on light conditions, and is defined as the depth at which primary production equals respiration. At the compensation depth the assimilation of carbon by primary producers is equal to metabolism of carbon. Lakes with positive heterograde $\mathrm{O}_{2}$-profile normally have high stratification stability and are not very wind exposed. The main reasons for heterograde $\mathrm{O}_{2}$-curve are high photosynthesis activity in metalimnion, a preferred depth for many algae because of the combination of good light and nutrient conditions. 
Table 3. Key biological characteristics of the manipulated Lake Breisjøen (B) and reference Lake Store Gryta (SG). Values are whole-lake volume-weighted means \pm standard deviation based on samples collected fortnightly or monthly during the ice-free season. Pre-treatment 1998-2000; treatment 2001-2003. Also shown are difference in Breisjøen relative to Store Gryta, and change in difference for the 3 treatment relative to 3 pre-treatment years. The change ascribable to treatment was tested by Random Intervention Analysis. Statistical significance: NS not significant; $* \mathrm{p}<0.1 ; * * \mathrm{p}<0.05 ; * * * \mathrm{p}<0.001$.

\begin{tabular}{|c|c|c|c|c|c|c|c|c|c|c|c|c|c|}
\hline \multirow[t]{2}{*}{ Parameter } & \multirow[t]{2}{*}{ Unit } & \multicolumn{3}{|c|}{ pre (1998-2000) } & \multicolumn{3}{|c|}{ treat (2001-2003) } & \multicolumn{2}{|c|}{ Change treat-pre } & \multicolumn{3}{|c|}{ delta B-SG } & \multirow{2}{*}{$\begin{array}{l}\text { RIA } \\
\text { signif }\end{array}$} \\
\hline & & $\mathrm{n}$ & B & SG & $\mathrm{n}$ & B & SG & B & SG & pre & post & post-pre & \\
\hline chl- $a$ & $\mu \mathrm{g} \mathrm{L}^{-1}$ & 42 & $1.57 \pm 0.45$ & $1.01 \pm 0.20$ & 32 & $1.59 \pm 0.56$ & $1.30 \pm 0.26$ & 0.02 & 0.29 & 0.56 & 0.29 & -0.28 & $* * *$ \\
\hline phytoplankton biomass & $\mu \mathrm{g}$ wet weight $\mathrm{L}^{-1}$ & 42 & $141 \pm 60$ & $111 \pm 44$ & 38 & $145 \pm 57$ & $120 \pm 41$ & 5 & 10 & 30 & 25 & -5 & NS \\
\hline primary production & $\mathrm{mgCm}^{-2}$ day $^{-1}$ & 42 & $71 \pm 49$ & $57 \pm 38$ & 38 & $73 \pm 46$ & $63 \pm 33$ & 2.7 & 6.1 & 13 & 10 & -3 & NS \\
\hline periphyton growth, 1-3 m & $\mathrm{mg}$ dry weight $125 \mathrm{~cm}^{-2} \mathrm{mo}^{-1}$ & 14 & $44 \pm 26$ & $61 \pm 45$ & 15 & $57 \pm 30$ & $35 \pm 21$ & 13 & -26 & -22 & 23 & 44 & $* * *$ \\
\hline periphyton growth, $5-10 \mathrm{~m}$ & $\mathrm{mg}$ dry weight $125 \mathrm{~cm}^{-2} \mathrm{mo}^{-1}$ & 14 & $24 \pm 7$ & $39 \pm 42$ & 15 & $39 \pm 25$ & $15 \pm 7$ & 15 & -24 & -15 & 24 & 39 & $* * *$ \\
\hline zooplankton biomass & $\mu \mathrm{g}$ dry weight $\mathrm{L}^{-1}$ & 21 & $39 \pm 23$ & $36 \pm 18$ & 21 & $29 \pm 14$ & $35 \pm 17$ & -10.1 & -1.7 & 2.7 & -5.7 & -8.4 & NS \\
\hline cladocera & $\mu \mathrm{g}$ dry weight $\mathrm{L}^{-1}$ & 21 & $26 \pm 18$ & $25 \pm 16$ & 21 & $11 \pm 11$ & $23 \pm 14$ & -15.5 & -2.6 & 0.8 & -12.1 & -12.9 & $*$ \\
\hline copepoda & $\mu \mathrm{g}$ dry weight $\mathrm{L}^{-1}$ & 21 & $8.7 \pm 4.1$ & $9.3 \pm 3.8$ & 21 & $9.6 \pm 5.0$ & $7.6 \pm 3.2$ & 0.9 & -1.7 & -0.6 & 2.0 & 2.6 & $*$ \\
\hline rotifera & $\mu \mathrm{g}$ dry weight $\mathrm{L}^{-1}$ & 21 & $4.2 \pm 4.1$ & $1.7 \pm 1.2$ & 21 & $8.7 \pm 9.9$ & $4.4 \pm 6.1$ & 4.5 & 2.7 & 2.5 & 4.3 & 1.9 & NS \\
\hline
\end{tabular}

After manipulation Lake Breisjøen no longer had a positive heterograde $\mathrm{O}_{2}$-curve. The significant deepening of the thermocline also significantly reduced the stratification stability. The elimination of the positive heterograde $\mathrm{O}_{2}$-curve was also expected as it is normally a consequence of photosynthesis activity near the thermocline, and a significantly deeper thermocline entails significant reduction in light and thereby primary production and subsequent increase in $\mathrm{O}_{2}$ from photosynthesis activity.

In general Lake Breisjøen had slightly lower concentrations of dissolved $\mathrm{O}_{2}$ than Lake Store Gryta. This is likely because Lake Breisjøen is somewhat more nutrient rich and receives more allochthonous compounds. After manipulation the $\mathrm{O}_{2}$ concentration in Lake Breisjøen increased and was slightly higher than in Lake Store Gryta. The main reasons are increased inputs of kinetic energy (caused by the propeller), lower thermal stability with greater opportunity for mixing, and much longer autumn turnover periods, i.e. earlier turnover and later ice-on. In more nutrient- or humic-rich lakes, however, a significantly larger increase in dissolved $\mathrm{O}_{2}$ would be expected after a similar thermocline deepening.

The observed relatively lower concentrations of $\mathrm{SO}_{4}$ and higher pH (Fig. 6, Table 2) can be explained by increased microbiological activity at the sediment-water interface, including increased reduction of $\mathrm{SO}_{4}$ and increased ammonification, induced by greater degree of circulation of the water mass and a larger sediment surface in contact with the mixed epilimnion.

The increased transparency may be caused by changes in vertical distribution of algal biomass. Before the manipulation the transparency was affected by the algal maximum located in the thermocline area. During the manipulation, however, the Secchi depth was located above the thermocline, and the distribution of algae in the water profile was more uniform. Alternatively the increase in Secchi depth may be due to a decrease in number of particles; the lower thermo- cline implies higher sedimentation velocity in the upper $10 \mathrm{~m}$ during the manipulation. The lower concentrations of particulate $\mathrm{C}$ and $\mathrm{N}$ suggest that the manipulation enhanced the sedimentation velocity of particulate matter.

A large increase in the biomass of Cyanophyceae was recorded in both lakes in 2002, with a significant peak in late August. This peak was probably a direct effect of the extremely warm August and September. The increase was primarily due to the species Merismopedia tenuissima, a common species in oligotrophic lakes with biomass maximum in autumn, often linked to high temperatures. These observations imply that the year-to-year natural variations in climate were larger than those caused by the manipulation.

The phytoplankton biomass in the epilimnion decreased in the manipulated Lake Breisjøen relative to Lake Store Gryta. This is probably related to the increased light limitation in the much deeper epilimnion of the mixed lake. The top-down control from zooplankton should be expected to decrease in Lake Breisjøen, due to the decrease in relative abundance of cladocerans (Fig. 10). This should have caused the phytoplankton biomass to increase rather than decrease. The observed decrease thus probably would have been even greater if the grazing pressure from zooplankton had been the same as before treatment. The decrease in phytoplankton biomass after artificial mixing and increased light limitation has also been observed in enclosure experiments (Diehl et al., 2005). The light limitation of the phytoplankton may also be reflected in the particulate C/P ratios in the two lakes; Lake Breisjøen had lower C/P-ratios relative to Lake Store Gryta during the treatment years (Fig. 11). This effect on producer stoichiometry was also observed in an enclosure study with artificial mixing (Diehl et al., 2005).

The changes in the taxonomic composition with higher biomass of the mixotrophic dinoflagellates and lower biomass of the autotrophic chlorophytes and diatoms, were probably also a result of increased light limitation during mixing in Lake Breisjøen. This increased light limitation 
Table 4. Numbers of taxa of phytoplankton observed in each of several major classes in Lakes Breisjøn and Store Gryta during the 3-year periods pre-treatment (1998-2000) and treatment (20012003). + indicates species first recorded after 2000; - indicates species not recorded after 2000. $\mu$-algal species come in addition but were not identified to the species level.

\begin{tabular}{|c|c|c|c|c|c|c|c|c|}
\hline \multirow[b]{2}{*}{ Class } & \multicolumn{4}{|c|}{ Breisjøen } & \multicolumn{4}{|c|}{ Store Gryta } \\
\hline & $\begin{array}{l}98-00 \\
\text { pre }\end{array}$ & + & - & $\begin{array}{l}01-03 \\
\text { treat }\end{array}$ & $\begin{array}{l}98-00 \\
\text { pre }\end{array}$ & + & - & $\begin{array}{l}01-03 \\
\text { treat }\end{array}$ \\
\hline $\begin{array}{l}\text { Blue-green algae } \\
\text { Cyanophyceae }\end{array}$ & 6 & 3 & 1 & 8 & 1 & 3 & 1 & 3 \\
\hline $\begin{array}{l}\text { Dinoflagellates } \\
\text { Dinophyceae }\end{array}$ & 9 & 1 & 4 & 6 & 7 & 1 & 1 & 7 \\
\hline $\begin{array}{l}\text { Green algae } \\
\text { Chlorophyceae }\end{array}$ & 39 & 15 & 9 & 45 & 26 & 7 & 6 & 27 \\
\hline $\begin{array}{l}\text { Yellow-green algae } \\
\text { Xanthophyceae }\end{array}$ & 2 & 0 & 0 & 2 & 2 & 0 & 0 & 2 \\
\hline $\begin{array}{l}\text { Golden algae } \\
\text { Chrysophyceae }\end{array}$ & 29 & 3 & 6 & 26 & 27 & 3 & 6 & 24 \\
\hline $\begin{array}{l}\text { Diatoms } \\
\text { Bacillariophyceae }\end{array}$ & 12 & 4 & 1 & 15 & 13 & 1 & 6 & 8 \\
\hline $\begin{array}{l}\text { Cryptomonads } \\
\text { Cryptophyceae }\end{array}$ & 6 & 1 & 1 & 6 & 6 & 0 & 1 & 5 \\
\hline $\begin{array}{l}\text { Euglenophytes } \\
\text { Euglenaphycea }\end{array}$ & 1 & 0 & 0 & 1 & 1 & 0 & 0 & 1 \\
\hline Total & 104 & 27 & 22 & 109 & 83 & 15 & 21 & 77 \\
\hline
\end{tabular}

provides a competitive advantage to the mixotrophic algae, which can obtain carbon and other nutrients from feeding on bacteria in addition to their autotrophic light-dependent primary production.

The increase in chlorophyll- $a$ content in the phytoplankton clearly demonstrates the algal strategy of keeping a sustainable primary production down to depths where it is no longer energetically favourable to increase the chlorophyll content in algae cells. The increase in chlorophyll compensates for the light attenuation by depth, but at a certain depth this strategy is no longer energetically profitable. This depth is probably close to the compensation depth, which is normally around twice the Secchi-disc depth, which means about $20 \mathrm{~m}$ in both lakes. This fits well with the changes in chlorophylla/algae ratio by depth in the both lakes. Lake Store Gryta had an increase in this ratio down to the bottom of the lake at $22 \mathrm{~m}$, while a reduction in the ratio was observed in Lake Breisjøen at the depth interval $26-31 \mathrm{~m}$. The fact that the thermocline depth in Lake Breisjøen during the manipulation was about equal to the compensation depth $(\approx 20 \mathrm{~m})$, might be an important reason why only minor changes in algal biomass were observed.

The increase in phytoplankton species richness might indicate better conditions for biological opportunism as a result of the increased turbulent mixing caused by the manipulation.

Increased growth potential of periphyton (benthic algae) during the manipulation may have several causes:
1. The manipulation caused a small reduction in total phytoplankton biomass in the epilimnion, and thus reduced the competition for nutrients, particularly phosphorus, between the benthic algae and the phytoplankton. This might increase the potential for increased periphyton biomass.

2. Before the manipulation, Lake Breisjøen had a significant primary production maximum at the depth interval 5-6 m. During the manipulation this maximum was eliminated. This elimination may have favoured periphyton growth in the uppermost lake depths as the phytoplankton biomass has decreased at these depths.

3. The epilimnion volume of Lake Breisjøen increased substantially during the manipulation, which meant larger access to nutrients as long as the concentrations of nutrients are unchanged in the epilimnion.

4. Increased circulation (water movements) during the manipulation reduced the diffusion gradient, causing increased access to nutrients.

5. Mean temperature and heat content increased significantly in depth interval $1-10 \mathrm{~m}$, after the manipulation. Increased temperature stimulates primary production.

A small increase in the chlorophyll- $a$ density in periphyton was documented in Lake Breisjøen during the thermocline deepening. Investigations from Norway show that about 0.1$1.0 \mu \mathrm{g}$ chlorophyll- $a \mathrm{~cm}^{-2}$ monthly accumulates on ceramic pots in oligotrophic, clearwater lakes (Lindstrøm, 1996). Monthly accumulation $>2 \mu \mathrm{g} \mathrm{cm}^{-2}$ was measured in Lake Breisjøen at $3 \mathrm{~m}$ depth, during the manipulation. This might be an effect of changes in the species composition of the periphyton community, but this was not investigated.

The species composition of zooplankton in the two lakes was characteristic for oligotrophic lakes in southeast Norway (Walseng and Karlsen, 2001). The total biomass of zooplankton (Table 3) was low in both lakes, as a direct consequence of low phytoplankton biomass and primary production. One difference between the lakes was the relatively large population of Daphnia galeata in Lake Store Gryta, a species not observed in Lake Breisjøen. Correspondingly, Lake Breisjøen hosted a good population of Daphnia cristata, a species not observed in Lake Store Gryta. This difference may be caused by a stronger predation pressure from planktivorous fish in Lake Breisjøen relative to Lake Store Gryta.

There are good indications that Thermocyclops oithonoides was favoured by the thermocline deepening. This species is a small, almost colourless copepod, and thus effectively protected against predators. The low predator pressure permits this species to be present in the pelagic zone. The increase in T. oithonoides during manipulation might be due to higher temperatures which favour an increased number of reproduction cycles per year. 
At higher altitudes and in large cold lakes, T. oithonoides has normally only 1-2 generations per year. This species is primarily present below the postglacial marine limit in southeast Norway. However, this species and its "twin species" Mesocylops leukarti are among the most common European species of cyclopoid copepods, and M. leukarti is distributed more widely also in southern Norway. Thus, changes in biomass and number of reproductive cycles per year for these two copepods might be a useful indicator of climate-induced effects in many lakes.

The deepening of the thermocline in Lake Breisjøen from 5-6 $\mathrm{m}$ down to about $20 \mathrm{~m}$ significantly changed the vertical distribution of zooplankton. As all samples were collected during the day, vertical day/night migrations did not influence the routine samples. The routine samples can thus be used to infer year-to-year variations. During the manipulation, a much larger amount of zooplankton was located deeper in the lake. While cladocerans and copepods showed a clear increase in biomass in the depth interval 26$31 \mathrm{~m}$, during the manipulation in Lake Breisjøen, the rotifers showed an increase in the depth intervals 7-12 $\mathrm{m}$ and 13$18 \mathrm{~m}$. The different location maxima by depth for different taxonomic groups of zooplankton might be due to different selection of food, different predator pressure, variation in migration properties and variation in other environmental factors influenced by water temperature (Diehl et al., 2005).

The fact that the lake is oligotrophic and clearwater is likely the main reason for the only minor changes in lake chemistry and biology. In oligotrophic lakes inputs from the lake catchment almost totally determine lake water chemistry. Internal lake biogeochemical processes are too weak to have major impacts. In more eutrophic and dystrophic lakes, on the other hand, internal processes are stronger, and thus in such lakes deepening of the thermocline can be expected to cause more dramatic changes (Danis et al., 2004).

Despite relatively minor changes during the 3 years of manipulation, there were many indications of the beginnings of possible longer-term changes in lake biology. These include reduced phytoplankton biomass in the epilimnion, a shift from autotrophic to more mixotrophic phytoplankton, a reduction of grazing pressure from zooplankton due to less cladocerans and more small cyclopoid copepods, as well as increased growth of benthic algae. There have been shifts in the relative abundances of various organism groups and species. That the macrophyte and fish communities did not change significantly may be due to the short duration of the experiment (3-years) relative to the response time of these organisms. Additional years of manipulation and monitoring are required to reveal possible long-term effects and the subsequent consequences for the lake ecosystem.

\section{Conclusions}

The dramatic manipulation of the thermocline at Lake Breisjøen resulted in large changes in thermal properties but surprisingly few and only small changes in water chemistry and biology. The epilimnion was deepened, stratification stability was reduced, autumn turnover occurred at a significantly higher water temperature, and ice-on was delayed by several weeks. After manipulation Lake Breisjøen no longer had a positive heterograde $\mathrm{O}_{2}$-curve. The lakewater became more transparent, apparently because of changes in the vertical distribution of algal biomass. The lower concentrations of particulate $\mathrm{C}$ and $\mathrm{N}$ suggest that the manipulation enhanced the sedimentation velocity of particulate matter.

The phytoplankton biomass in the epilimnion decreased in the manipulated Lake Breisjøen. This was probably related to the increased light limitation in the much deeper epilimnion of the mixed lake. The changes in the taxonomic composition with higher biomass of the mixotrophic dinoflagellates and lower biomass of the autotrophic chlorophytes and diatoms, were probably also a result of increased light limitation during mixing. The increase in phytoplankton species richness suggests better conditions for biological opportunism as a result of the increased turbulent mixing caused by the manipulation. There are good indications that zooplankter Thermocyclops oithonoides was favoured by the thermocline deepening.

The fact that the lake is oligotrophic and clearwater is likely the main reason for the only minor changes in lake chemistry and biology. Despite relatively minor changes during the 3 years of manipulation, there were many indications of the beginnings of possible longer-term changes in lake biology. Additional years of manipulation and monitoring are required to reveal possible long-term effects and the subsequent consequences for the lake ecosystem.

Acknowledgements. The THERMOS project was financed in part by the Research Council of Norway as a Strategic Institute Project and the Norwegian Institute for Water Research. We thank the Public Health Department, the Water- and Wastewater Department, and the Forest Department of the City of Oslo for help in conjunction with THERMOS. S. Kroken, Institute for Technical Studies, Norwegian Agricultural University kindly provided climate data for the station at Ås.

Much of the field work was conducted by students from the Department of Limnology, University of Oslo (N. T. Dahl, T. M. Gjøvik, T. C. Jensen, S. Larsen, P. K. Rødsdalen, M. Seland, E. Thorbjørnsen and K. Urkedal). We also thank I. Bescan and T. Mortensen at NIVA for technical assistence.

Edited by: P. Dillon and R. F. Wright 


\section{References}

Carpenter, S. R., Frost, T. M., Heisley, D., and Kratz, T. K.: Random intervention analysis and the interpretation of whole-ecosystem experiments, Ecology, 70, 1142-1152, 1989.

Danis, P. A., von Grafenstein, U., Masson-Delmotte, V., Planton, S., Gerdeaux, D., and Moisselin, J.-M.: Vulnerability of two European lakes in response to future climatic changes, Geophys. Res. Lett., 31, L21507, doi:10.1029/2004GL020833, 2004.

Diehl, S., Berger, S., and Wohrl, R.: Flexible nutrient stoichiometry mediates environmental influences, on phytoplankton and its resources, Ecology, 86, 2931-2945, 2005.

DN: Nasjonal rødliste for truede arter i Norge 1998, Norwegian Red List 1998, DN-rapport 3, Directorate for Nature Management, Trondheim, Norway, 1999.

Faafeng, B., Berge, D., and Tjomsland, T.: Planteplanktonets primærproduksjon. III Beregning av primærproduksjon ved insitu metoden, NIVA-rapport FR-458, Norwegian Institute for Water Research, Oslo, Norway, 1982.

Lindstrøm, E.-A.: The Humic Lake Acidification Experiment (Humex): Impacts of acid treatment on periphyton growth and nutrient availability in Lake Skjervatjern, Norway, Environ. Int., 22, 629-642, 1996.
Murtaugh, P. A.: On rejection rates of paired intervention analysis, Ecology, 83, 1752-1761, 2002.

RegClim: Norges klima om 100 år. Usikkerhet og risiko, Norwegian Meteorological Institute, Oslo, 2005.

Saksgard, R. and Hesthagen, T.: A 14-year study of habitat use and diet of brown trout (Salmo trutta) and Arctic charr (Salvelinus alpinus) in Lake Atnsjoen, a subalpine Norwegian lake, Hydrobiologia, 521, 187-199, 2004.

Schindler, D. W.: Whole-lake experiments at the Experimental Lakes Area, in: Ecosystem Experiments, edited by: Mooney, H. A., Medina, E., Schindler, D. W., Schulze, E. D., and Walker, B. H., 121-139, SCOPE 45, Wiley and Sons, Chichester, UK, 268 pp., 1991.

Schindler, D. W., Bayley, S. E., Parker, B. R., Beaty, K. G., Cruikshank, D. R., Fee, E. J., Schindler, E. U., and Stainton, M. P.: The effects of climatic warming on the properties of boreal lakes and streams at the Experimental Lakes Area, northwestern Ontario, Limnol. Oceanogr., 41, 1004-1017, 1996.

Skjelkvåle, B. L., Mannio, J., Wilander, A., and Andersen, T.: Recovery from acidification of lakes in Finland, Norway and Sweden 1990-1999, Hydrol. Earth Syst. Sci., 5, 327-338, 2001, http://www.hydrol-earth-syst-sci.net/5/327/2001/.

Walseng, B. and Karlsen, L. R.: Planktonic and littoral microcrustaceans as indices of recovery in limed lakes in SE Norway, Water Air Soil Poll., 130, 1313-1318, 2001. 